\title{
Research Misconduct: The Cardinal Sin
}

\author{
Prabodh Risal ${ }^{*}$
}

"I've been imitated so well I've heard people copy my mistakes" -Jimi Hendrix, a famous guitarist express his concern about the plagiarism. Plagiarism is not only a concern in the field of music, arts, cinema and literature but also a major issue in scientific research. Plagiarisms including fabrication and falsifying data are foremost scientific misconduct [1]. Other scientific misconducts include authorship and conflict of interest [2].

A joint COPE/BMJ consensus statement on research misconduct in the UK defined research misconduct as the "Behavior by a researcher, intentional or unintentional that do not meet or fulfill the scientific and ethical standards" [3].

Misconduct in research is a serious issue because it can put patient at risk by influencing clinical practices [4]. It is also a waste of time, effort and money and results public mistrust in science [5, 6].

In a developing country like Nepal, number of research publication is increasing, because of the obligatory requirement for promotion of an academic position. But research has not been conducted in Nepal yet to see the magnitude and factors related to research misconduct. However, sporadic news in media has shed light on occurrence of research misconducts. University Grant Commission (UGC), Nepal released few public notices recently concerning research misconduct [7] and requested the affiliated institution to take necessary action including future debarment for grant application to the accused. In the year 2008, Kathmandu University medical journal retracted the article published in its earlier issue after editorial board being informed about severe form of plagiarism. The authors were fined and barred from publication in the journal for certain time period. Meanwhile, their misconduct was reported to the respective institutions and councils [8]. This shows that as the research environment and publications are increasing, research misconduct is also increasing. Therefore, there is a need of effective national mechanism to address it.
Factors associated with research misconduct in developed countries may be different than the factors in Nepal. Many studies say that increase availability of internet and online free access to journals may have caused increased plagiarism [9]. Language barrier, lack of mentorship to young researcher and lack of awareness regarding plagiarism may be some easily modifiable factors associated with research misconduct [10-13]. Whereas, personal values and attitude of taking shortcut achievement as cleverness and pride in society, or even thinking of never being caught or light consequences of being caught may be the difficult to modify factors associated with plagiarism in developing countries including Nepal [13]. On other hand, trying to be modest with peers and blinding self towards their awful act of research misconduct is a different factor that may encourage research misconduct and prevent correction on time [12].

The Nepal Health Research Council (NHRC) previously established as Nepal Health Research Committee (1982) under the Ministry of Health is mostly concern with ethical issues in health research and provides ethical approval for conducting research [14]. But unlike developed countries, regulatory body that monitors research integrity has not been established in Nepal. Therefore, NHRC should start separate committee to check research integrity and misconduct as soon as possible. So that when a case is registered by an individual, the committee could investigate and suggest necessary action in case of proven research misconduct.

\section{Final comment and proposed way out}

Research misconduct, a sinful act has to be addressed properly on time to prevent its consequences. Initially, we need to know burden and contributing factors of research misconduct in Nepal. Then it could be minimized by effective measures like increasing awareness through proper training and workshops. One can also encourage peers to speak up against the act of misconduct done by the colleagues in their respective field or institution. Similarly, the host university or institution may be requested to take necessary

${ }^{1}$ Department of Biochemistry, Kathmandu University School of Medical Sciences, Dhulikhel, Nepal

Correspondence to: Dr. Prabodh Risal, Associate Professor, Biochemistry, Kathmandu University School of Medical Sciences, Dhulikhel, Nepal. Email: prabodh07@hotmail.com

(C) 2015 Nepalese Association for Clinical Chemistry 
action if their employee is proved to be involved in research misconduct. Finally, NHRC may come one step ahead to handle such type of issues so that research misconduct could be prevented when it is still in its infancy.

\section{REFERENCES}

1. Dooley, J. J., and Kerch, $\mathrm{H}$. M. Evolving research misconduct policies and their significance for physical scientists. Science and Engineering Ethics, 2000; 6: 109-121.

2. Dale J. Benos, Jorge Fabres, John Farmer et al. Ethics and scientific publication. $A d V$ Physiol Educ, 2005; 29: 5974.

3. A consensus statement on research misconduct in the UK. BMJ/COPE high level meeting 12 January 2012 [Last accessed on 2015 September 06]. Available from:

http://publicationethics.org/fi les/A_consensus_statement_o $\mathrm{n} \_$research_misconduct_in_t he_UK.pdf

4. Al-Marzouki S, Roberts I, Marshall T, Evans S. The effect of scientific misconduct on the results of clinical trials, A Delphi survey. Contemp Clin Trials, 2005; 26:331-7.

5. Stefania M. Mojon-Azzia Daniel S. Mojona. Scientific Misconduct: From Salami Slicing to Data Fabrication.
Ophthalmic Res., 2004; 36:1-3.

6. Redman, B. K., Caplan, A. L. Off with their heads: The need to criminalize some forms of scientific misconduct. Journal of Law, Medicine and Ethics; 2005; 33: 345-348.

7. University Grant Commission, notice regarding enlistment in blacklist. [Last accessed on 2015 September 06]. Available from: http://www.ugcnepal.edu.np/ notices/enlistment-in-blackl\#

8. Consultant Editor's Note regarding publication of a duplicate article: "Correlation between serum-ascites albumin concentration gradient and endoscopic parameters of portal hypertension (PMID: 16449830; Oct Dec 2005)" KUMJ, 2008; 23: 301.

9. Brown GO. Out of the way: how the next copyright revolution can help the next scientific revolution. PLOS Biol, 2003; 1:30-31.

10.Yongyan Li, Text-Based
Plagiarism in Scientific Publishing: Issues, Developments and Education. Sci Eng Ethics, 2013; 19:1241-1254.

11. Habermann B, Broome M, Pryor ER, Ziner KW. Research coordinators' experiences with scientific misconduct and research integrity. Nurs Res., 2010; 59:51-7.

12.Bahadori M., Izadi M., Hoseinpourfard $M$. Plagiarism: Concepts, Factors and Solutions. Iranian Journal of Military Medicine, 2012; 14: 168-177.

13.Elizabeth Heitman, Sergio Litewka, International Perspectives on Plagiarism and Considerations for Teaching International Trainees. Urol Oncol. 2011; 29: 104-108.

14. National Ethical Guidelines for Health Research in Nepal and Standard Operating Procedures [Accessed on 23, August 2015]. Available from:

http://nhrc.org.np/guidelines 